ENTREPRENEURSHIP AND SUSTAINABILITY ISSUES

ISSN 2345-0282 (online) http://jssidoi.org/jesi/

2021 Volume 8 Number 3 (March)

http://doi.org/10.9770/jesi.2021.8.3(18)
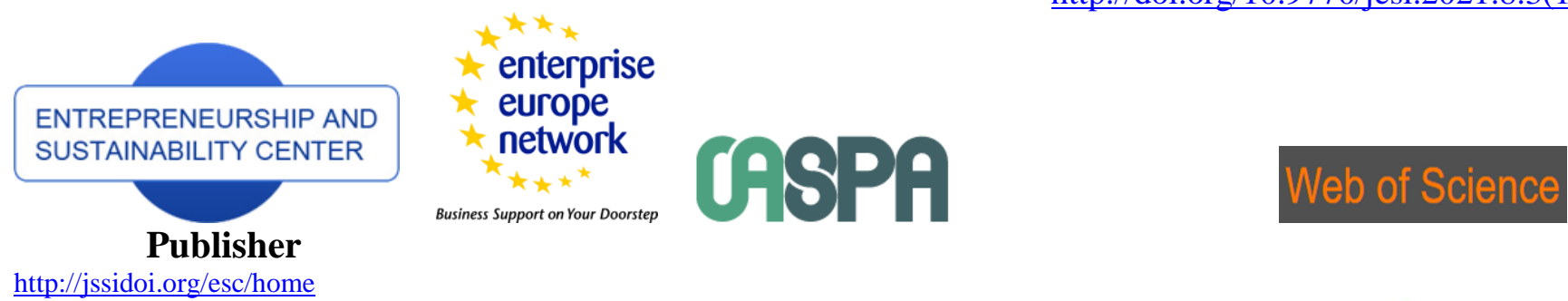

$\underline{\mathrm{http}: / / \text { jssidoi.org/esc/home }}$

Clarivate

\title{
ENHANCING RISK MANAGEMENT CULTURE FOR SUSTAINABLE GROWTH OF ASIA COMMERCIAL BANK - ACB IN VIETNAM UNDER MIXED EFFECTS OF MACRO FACTORS
}

\section{Le Dinh Hac ${ }^{1}$, Dinh Tran Ngoc Huy ${ }^{2}$, Nguyen Ngoc Thach ${ }^{3}$, Bui Minh Chuyen ${ }^{4}$, Pham Thi Hong Nhung ${ }^{5}$, Tran Duc Thang ${ }^{6}$, Tran Tuan Anh ${ }^{7}$}

${ }^{1,3}$ Banking University HCMC, Ho Chi Minh city, Vietnam (corresponding)

${ }^{2}$ MBA, Banking University HCMC, Ho Chi Minh city, Vietnam - International University of Japan, Japan (corresponding)

${ }^{4}$ Institute of Financial Training, Vietnam

${ }^{5}$ Academy of Finance, Vietnam

${ }^{6}$ National Economics University (NEU), Vietnam

${ }^{7}$ Thai Nguyen University of Economics and Business Administration (TUEBA), Vietnam

E-mails: ${ }^{1}$ hacld@buh.edu.vn ; ${ }^{2}$ dtnhuy2010@gmail.com ; ${ }^{3}$ thachnn@buh.edu.vn ;

ㅁuiminhchuyen@ift.edu.vn; ${ }^{5}$ phamnhung@hvtc.edu.vn; ${ }^{6}$ tranducthang@neu.edu.vn ; ${ }^{7}$ tuananhtueba@gmail.com

Received 15 May 2020; accepted 11 January 2021; published 30 March 2021

\begin{abstract}
For sustainable growth, macro policy makers will need to look at risk management in banking industry and impacts of macro factors on market risk in order to adjust policies and build risk management culture in banking system. What we need to adjust in trade balance, risk free rate and other policies? This is one of reasons for us to conduct this study. This paper measures the Beta CAPM in famous model under impacts of both macro internal and external variables during low inflation time 2015-2020 in the country. The evidence is the fundamental role of risk management in commercial bank has been increasing with new perspectives in management, corporate governance and risk management models. We will estimate effects in risk measurement of one of big listed Vietnam commercial bank, Asia commercial bank (ACB) during the low inflation period 2015-2020 with semiannual data. Through using analysis, synthesis statistics methods, and dialectical materialism method, combined with econometric model with 9 macro variables, we figure out that CPI has a positive correlation with Beta CAPM of ACB, while Risk free rate (Rf) and lending rate have negative correlation with Beta CAPM of the bank. It implies that increase in inflation, together with decrease in Rf and lending rate will increase market risk. Then, one of its major findings is the suggestion of macro and risk management policies for bank and relevant government agencies. Our recommendation can be used for reference and expand researches in many other emerging markets.
\end{abstract}

Keywords: market risk management; risk culture; beta CAPM; low inflation; banking industry; Vietnam, policy

Reference to this paper should be made as follows: Hac, L.D., Huy, D.T.N., Thach, N.N., Chuyen, B.M., Thang, T.D., Nhung, P.T.H., Thang, T.D., Anh, T.T. 2021. Enhancing Risk Management Culture for Sustainable Growth of Asia Commercial Bank -ACB in Vietnam under Mixed Effects of Macro Factors. Entrepreneurship and Sustainability Issues, 10(3), 291-307. http://doi.org/10.9770/jesi.2021.8.3(18)

JEL Classifications: M1, M21, G30 
ENTREPRENEURSHIP AND SUSTAINABILITY ISSUES

ISSN 2345-0282 (online) http://jssidoi.org/jesi/

2021 Volume 8 Number 3 (March)

http://doi.org/10.9770/jesi.2021.8.3(18)

\section{Introduction}

Nowadays, under 4.0 industry and Basel impacts, Vietnam banks pay attention more to risk management, especially perspectives in governance, management and risk models. This is the 1st reason we conduct this research paper. Corporate culture can be defined as the set of values and standards of beliefs, behaviors, perception and thinking methods that are recognized by everyone in the company, thinking and acting as a habit. Corporate culture is like a person's personality and spiritual life, influencing its lifestyle and behavior. Building a company culture determines the success, failure and long-term survival of each business. Hence, we can see risk management culture will include perception and thinking methods relating to risk and risk management within the firm.

This study will calculate and figure out not only inflation but other macro factors, both internal and external indicators affecting the market risk level during the low inflation time (2015-2020). Asia Commercial Bank (ACB) is one of big listed joint stock commercial bank in Vietnam, which achieved significant growth in past years. Having endured heavy losses in 2012, the bank returned to positive growth on the first stage of the 20142018 development roadmap, with particularly impressive figures in terms of total assets and profits. before tax reported at the end of 2014. Phase two (2015-2016) focuses on building the bank's capacity when core values and competencies are maintained and strengthened, in addition, product and service packages are tailored to each segment. customers, more specifically to improve their competitiveness and better serve the target audience. During this period, ACB's technology platform was also developed by gradually transforming the core system as well as by deploying many IT applications into use. Organizational and operational restructuring is also being implemented. The final phase, which starts in 2017 and will be completed in 2018, focuses on positioning ACB once again as one of the top banks in Vietnam, especially through key metrics. including: customer satisfaction, sustainable financial results, risk management, performance and business ethics.

Our research purpose:

We aim to provide recommendations, via an econometric model, for macro and risk management policies and for building risk management culture at Vietnam commercial banks in order to prevent and control risks better in a changing world with compounding impacts from Covid 19 and trade war. Our suggestion smight be references fro other emerging markets.

We will structure the paper with introduction, research issues, literature review, conceptual theories and methodology. Next is research findings/results. Then we present discussion and conclusion and policy suggestion.

\section{Previous studies}

\subsection{Research questions}

We will explore key matters as follow:

Question 1: What are impacts of internal and external macro variables s on market risk measurement of Asia commercial bank (ACB)?

Question 2: What are risk management culture building plans for ACB to reduce potential risks?

There are hypotheses will be checked:Hypothesis 1: Beta CAPM of listed bank (ACB) will increase if inflation increase and it will decrease if GDP growth increases.

Hypothesis 2: If exchange rate decreases (VND appreciation), beta CAPM will decrease. 


\section{ENTREPRENEURSHIP AND SUSTAINABILITY ISSUES}

ISSN 2345-0282 (online) http://jssidoi.org/jesi/

2021 Volume 8 Number 3 (March)

http://doi.org/10.9770/jesi.2021.8.3(18)

Hypothesis 3: With the above reasons in Covid 19 and US-China commerce war and low inflation, Beta CAPM of ACB will impose a high risk value or (>) 1 .

\subsection{Literature review}

First, in 3 factor model, Fama and French (2004) mentioned stock return is affected by value and size. Then, Anderson et al. (2005) pointed that beta value on stock exchange will change according to macro indicators such as industrial manufacturing growth index and effects of macro factors large enough to be meaningful. Hojat (2015) said since the outset of the industrial revolution, the equity market has played an instrumental role in the progress of economic production. Singh et al (2010) revealed that exchange rate and GDP seem to affect returns of all portfolios, while inflation rate, exchange rate, and money supply were having negative relationship with returns for portfolios of big and medium companies. Tahmidi et al (2011) said net lending and net borrowing had significant negative effect on market risk premium in Canada, whereas in Germany and Sweden the relationship was not significant.

Next, Ohdner and Zachrison (2016) has presented research results showing that with Beta as risk measurement, investors will demand higher return when holding higher beta stocks, on the announcement date of monetary policies. Adhikari (2015) said based on cross-sectional approach it is revealed that size and profitability are positively associated with the systemic risk, while the dividend payment is negatively related to the risk. The results thus indicate that financial factors have significant predictive power for the systemic risk of a stock investment in Nepal.

Then, Ahmad and Ramzan (2016) stated the macroeconomic factors have important concerns with stocks traded in the stock market and these factors make investors to choose the stock because investors are interested to know about the factors affecting the working of stock to manage their portfolios. Gay (2016) found no significant relationship was found between respective exchange rate and oil price on the stock market index prices of either BRIC country, this may be due to the influence other domestic and international macroeconomic factors on stock market returns. Nawaz et al. (2017) said the consequences of 29 cement industries showed that there is a huge relationship between industry size, operating efficiency, and profitability with 181 systematic risk and results similar to past studies while liquidity and financial leverage have not a significant relationship with beta (systematic risk). Puspitaningtyas (2017) said the financial information is measured in four accounting variables, i.e. financial leverage, liquidity, profitability, and firm size.

Moreover, Curran and Velic (2018) took advantage of global data on stock prices and highly value CAPM model compared to previous models. They show that in the countries with higher level of openness of financial markets, fluctuation in exchange rate and bigger size of economy receive higher systematic covariance. Also there is negative correlation between world reserves and systematic risk. Kola et al (2018) used factors affecting bank profitability such as bank internal factors, industry, and macroeconomic (external) factors. Klimontowiz (2019) provided direction for banks' decision makers concerning innovativeness' factors that should be taken into account in the process of building competitive advantage and sustainable market performance. Sadeghzadeh (2018) found increases of on current ratio, on the ratio of equity capital ratio to tangible assets, on the ratio of own capital to assets, on accounts receivables turnover rate, net profits, on the ratio of equity, the marketing values of companies, on the ratio of book value increased share earnings in a short term and increases of on the ratio of debt to tangible assets and asset turnover decreased share earnings in a short term significantly. Siregar and D. (2019) showed that there is difference of systematic factors influence to stock return in three observation period. Increased market risk and economic growth, increase stock returns. Tahir et al. (2020) found higher availability of private credit in the host country results in lower dividend repatriation. Huy et al. (2020) show that the increase in GDP growth and lending rate and risk free rate has a significant effect on increasing VCB stock price with the highest impact coefficient, the second is decreasing the exchange rate, finally is a slight decrease in S\&P500. 


\section{ENTREPRENEURSHIP AND SUSTAINABILITY ISSUES}

ISSN 2345-0282 (online) http://jssidoi.org/jesi/

2021 Volume 8 Number 3 (March)

http://doi.org/10.9770/jesi.2021.8.3(18)

Kozaric \& Dzelihodzi (2020) confirm the significance of macroeconomic for non-performing loans control and financial stability maintenance. Kruscovic (2020) pointed countries with inflation targeting have a lower grate of economic growth. Masood et al. (2020) said there is significant influence of terrorism activities on financial stock market of five selected countries. Nain et al 92020) found uncertainty influences the effectiveness of monetary policy shock. Rakshit et al (2020) reveal that in India, a higher degree of bank competition is positively as sociated with the prevalence of non-performing loans. Okpamen et al. (2020) said firms needed to encourage adequate interlocking members who have diverse professional training, high social net worth and experience (experience hypothesis) to positively influence effective management and financial performance of listed firms in Nigeria. Pena (2020) mentioned the interferences among some financial, economic and monetary variables are checked as an indicator of economic performance in the long run and for the monetary policy applied between the Great Moderation (GM) of 1987-2001 and the Global Financial Crisis of 2007-2009. Rakotonirainy et al. (2020) stated the horizon of capital prediction shows that banking sector reacts most to a GDP shock.

The below table 1 will summarize previous studies relating to risk management under macro impacts topic:

Table 1. Summarizing previous studies

\begin{tabular}{|c|c|c|}
\hline Domestic researches & Authors name & Results, contents \\
\hline $\begin{array}{l}\text { 2. The econometric model for stock } \\
\text { prices in the period 2008-2011 - Case of } \\
\text { stock prices ACB, VNIndex, Rf }\end{array}$ & Đinh Trần Ngọc Huy (2015) & $\begin{array}{l}\text { Analyze the impact of VNIndex and internal and } \\
\text { external macro variables on the stock price of ACB. }\end{array}$ \\
\hline $\begin{array}{l}\text { 5. Systemic risks in banking business - } \\
\text { periods of crisis }\end{array}$ & $\begin{array}{l}\text { Nguyễn Thanh Bé \& Bùi Quang } \\
\text { Hưng (2019) }\end{array}$ & $\begin{array}{l}\text { Presented in Vietnam, the risk management system at } \\
\text { commercial banks has been paid attention to a certain } \\
\text { extent in the past few years, but due to its structural and } \\
\text { technical limitations, this system has not can meet the } \\
\text { complex requirements of a modern commercial bank } \\
\text { operating in the current risky environment. }\end{array}$ \\
\hline $\begin{array}{l}\text { 6. Factors affecting the return rate of } \\
\text { listed stocks from the Fama French 5- } \\
\text { factor model }\end{array}$ & Trịnh Minh Quang et al (2019) & $\begin{array}{l}\text { Referring to factors of market change will strongly } \\
\text { affect the share prices of large companies }\end{array}$ \\
\hline International researches (summary) & Authors name & Results \\
\hline
\end{tabular}




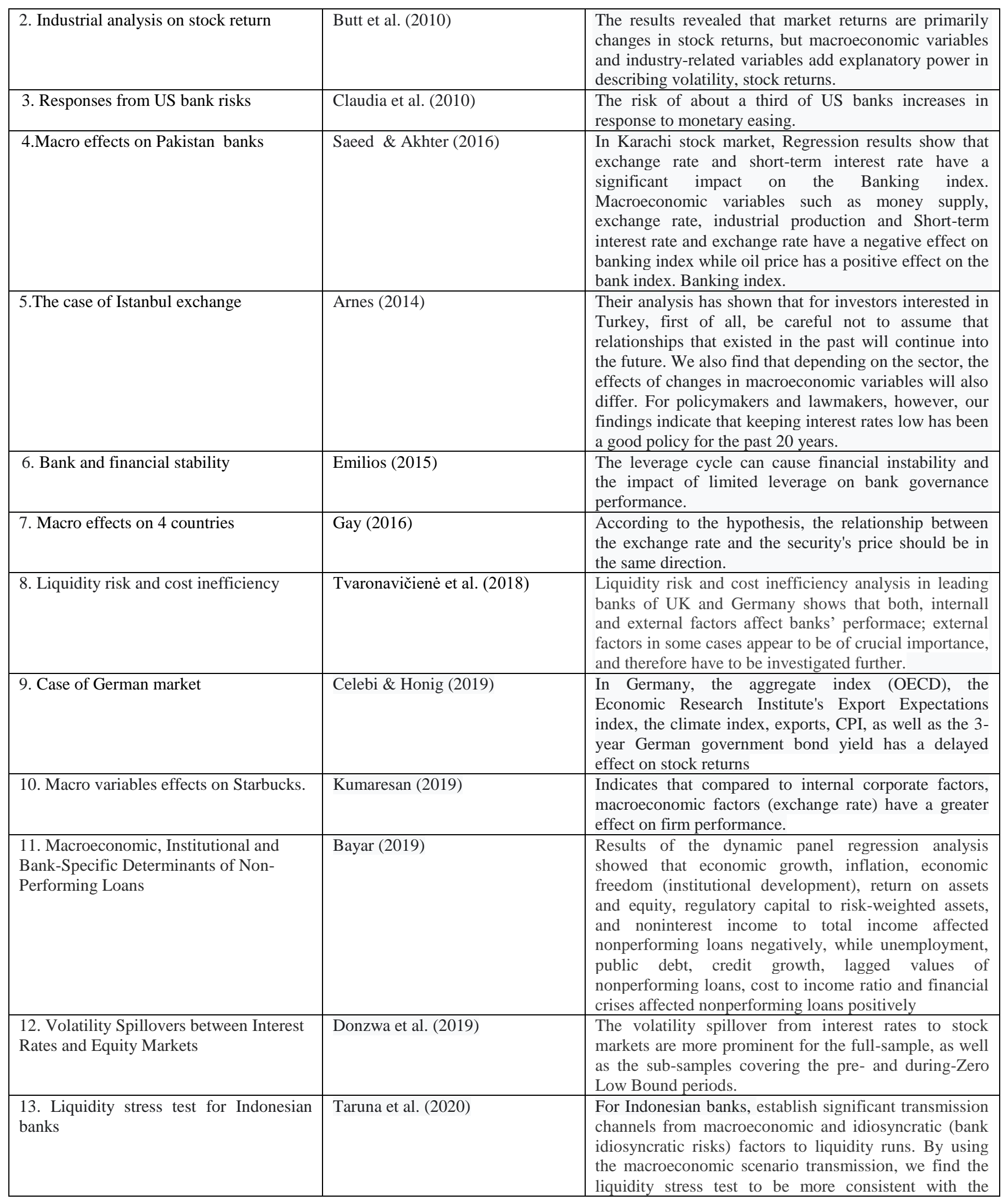


ENTREPRENEURSHIP AND SUSTAINABILITY ISSUES

ISSN 2345-0282 (online) http://jssidoi.org/jesi/

2021 Volume 8 Number 3 (March)

http://doi.org/10.9770/jesi.2021.8.3(18)

\begin{tabular}{|c|c|c|}
\hline & & solvency stress test. \\
\hline 14. Financial stability & Vucinic (2020) & $\begin{array}{l}\text { Stresses out an importance of international cooperation } \\
\text { of regulators in order to preserve financial stability in } \\
\text { the recent world of technological changes and } \\
\text { innovations. }\end{array}$ \\
\hline 15. Financial Literacy - Indonesia & Tkacova et al. (2018) & $\begin{array}{l}\text { Results show that all financial attitudes, behaviour and } \\
\text { literacy variables positively affect financial literacy and } \\
\text { wellbeing. }\end{array}$ \\
\hline $\begin{array}{l}\text { 17. Capital Flow and Bank Risk Taking } \\
\text { Behavior }\end{array}$ & Rumondor \& Bary (2020) & $\begin{array}{l}\text { Capital inflows, in the form of portfolio investment, is } \\
\text { significant in raising risk-taking behavior. Large banks } \\
\text { are less aggressive in their risk-taking behavior vis-à-vis } \\
\text { smaller banks. }\end{array}$ \\
\hline 19. PBC Financial Strength and Policy & Sun (2020) & $\begin{array}{l}\text { Alternative financial strength indicator plays different } \\
\text { role in helping the People's Bank of China achieve its } \\
\text { alternative policy objectives. }\end{array}$ \\
\hline 20. Financial vulnerability in Malaysia & Kuek (2020) & $\begin{array}{l}\text { Reveal that financial vulnerability shock catalysed } \\
\text { significant negative effects on economic activity. }\end{array}$ \\
\hline
\end{tabular}

\subsection{Methodology}

Values of Beta CAPM are calculated from data of stock price on HOSE and HNX stock market during 20152020. This is L-inflation time and China-US commerce war. We use analytical and synthesis methods and dialectical materialism method. Analytical data is from the situation of listed bank (ACB) in Vietnam stock exchange.

Analysis of the effects of 9 macro variables on market risk of listed commercial bank, Asia commercial bank (ACB). Weekly data collected from 2015-2020 for ACB stock price to measure Beta and other macro data from reliable sources such as the General Statistics Office and commercial banks. Beta CAPM is a function with 9 macro variables (x1: GDP growth rate (g), x2: Risk-free rate Rf (i), x3: Loan interest rate (r), x4: Exchange rate (ex_rate), x5: S\&P 500, x6: VNIndex, x7 : trade balance, x8: industrial production index, x9: CPI). We use OLS regression.

Reasons why we chose these macro factors:

First, we recognize market risk is systemic risk affected by all market indicators and macro factors.

Second, in global financial market, developing economies receive impacts from big economies such as US, China. Third, Based on our analysis and results, Macro policies and risk management plans are recommended for both Asia commercial ban (ACB), relevant organizations and government.

Total 9 macro variables are described with sources in the below table 2: 


\section{ENTREPRENEURSHIP AND SUSTAINABILITY ISSUES}

ISSN 2345-0282 (online) http://jssidoi.org/jesi/

2021 Volume 8 Number 3 (March)

http://doi.org/10.9770/jesi.2021.8.3(18)

Table 2. Variables description (source: author's synthesis from Bureau statistics, commercial banks, HOSE and HNX stock exchange in Vietnam)

\begin{tabular}{|c|c|c|c|}
\hline Variable name & Sign & Data source & Reference source \\
\hline \multicolumn{4}{|l|}{ Dependent variable } \\
\hline Market risk (BetaCAPM) & BetaCAPM & HOSE and HNX & $\begin{array}{l}\text { Treynor (1962), Sharpe (1964), Lintner (1965), } \\
\text { Mossin (1966) }\end{array}$ \\
\hline \multicolumn{4}{|l|}{ Independent variables } \\
\hline GDP growth & $\mathrm{g}$ & Bureau statistics & Huy et al. (2021) \\
\hline VNIndex & VNindex & HOSE and HNX & Huy et al. (2020) \\
\hline Risk free rate & $\mathrm{Rf}$ & German market & Celebi \& Honig (2019) \\
\hline Lending rate & $\mathrm{r}$ & Istanbul financial market & Arnes (2014) \\
\hline Exchange rate & Ex_rate & Pakistan financial market & Saeed \& Akhter (2016) \\
\hline S\&P500 & SP500 & NYSE & Huy et al (2020) \\
\hline BOT(trade balance) & BOT & Bureau statistics & Author synthesis \\
\hline IM (Industrial manufacturing index) & IM & Bureau statistics & Author synthesis \\
\hline
\end{tabular}

In the below table, we see statistics for 9 variables. The table indicated that std.deviation of Exchange rate and trade balance and VNIndex with highest values, while std. deviation of CPI, Rf as lowest values (Figure 1).

\begin{tabular}{|l|c|c|c|c|c|c|c|c|c|c|}
\hline & BETACAPM & CPI & G & IM & R & RF & VNINDEX & SP500 & EX RATE & BOT \\
\hline Mean & 0.982799 & 0.027618 & 0.060609 & 167.8909 & 0.095691 & 0.042000 & 800.6455 & 2576.246 & 22791.45 & -60.45455 \\
\hline Median & 0.754649 & 0.028100 & 0.067600 & 147.4000 & 0.100000 & 0.037000 & 825.1000 & 2506.850 & 22920.00 & -100.0000 \\
\hline Maximum & 3.374341 & 0.047400 & 0.070800 & 267.2000 & 0.110000 & 0.061800 & 984.2400 & 3230.780 & 23230.00 & 400.0000 \\
\hline Minimum & 0.404721 & 0.006300 & 0.018100 & 127.3000 & 0.080000 & 0.019500 & 579.0300 & 2043.940 & 21780.00 & -500.0000 \\
\hline Std. Dev. & 0.825392 & 0.012590 & 0.015273 & 44.01387 & 0.010825 & 0.014450 & 161.5812 & 416.1722 & 443.6015 & 267.7728 \\
\hline Skewness & 2.458229 & -0.162938 & -2.140463 & 1.322279 & -0.137303 & 0.114349 & -0.254721 & 0.208963 & -1.103011 & 0.573461 \\
\hline Kurtosis & 7.810966 & 2.045666 & 6.685526 & 3.491429 & 1.756312 & 1.716206 & 1.437038 & 1.681378 & 3.459091 & 2.763409 \\
\hline & & & & & & & & \\
\hline Jarque-Bera & 21.68694 & 0.466101 & 14.62515 & 3.316126 & 0.743494 & 0.779363 & 1.238592 & 0.876987 & 2.327097 & 0.628561 \\
\hline Probability & 0.000020 & 0.792114 & 0.000667 & 0.190508 & 0.689529 & 0.677272 & 0.538323 & 0.645007 & 0.312376 & 0.730314 \\
\hline & & & & & & & & & \\
\hline Sum & 10.81079 & 0.303800 & 0.666700 & 1846.800 & 1.052600 & 0.462000 & 8807.100 & 28338.71 & 250706.0 & -665.0000 \\
\hline Sum Sq. Dev. & 6.812718 & 0.001585 & 0.002333 & 19372.21 & 0.001172 & 0.002088 & 261085.0 & 1731993. & 1967823. & 717022.7 \\
\hline
\end{tabular}

Figure 1. Descriptive statistics for 9 macro variables (source: data synthesis from Bureau statistics, commercial banks, HOSE and HNX stock exchange in Vietnam) 


\section{ENTREPRENEURSHIP AND SUSTAINABILITY ISSUES}

ISSN 2345-0282 (online) http://jssidoi.org/jesi/

2021 Volume 8 Number 3 (March)

http://doi.org/10.9770/jesi.2021.8.3(18)

\section{Findings}

\subsection{Overall Analysis}

First we look at the below figure 2, we find out correlation matrix of internal variables. We see that Increase in industrial manufacturing index will cause Beta CAPM increases while decrease in CPI will make it decreases.

\begin{tabular}{|c|c|c|c|c|c|c|c|c|c|c|}
\hline \multicolumn{11}{|c|}{ Correlation Matrix } \\
\hline & BETACAPM & $\mathrm{CPI}$ & G & IM & $\mathrm{R}$ & RF & VNINDEX & SP500 & EX RATE & BOT \\
\hline $\mathrm{CPI}$ & 0.301348 & 1.000000 & 0.170563 & 0.429462 & -0.404467 & -0.145300 & 0.410100 & 0.239791 & 0.345255 & -0.332970 \\
\hline IM & 0.407736 & 0.429462 & 0.155701 & 1.000000 & 0.077944 & 0.117218 & 0.059045 & -0.197708 & -0.070142 & -0.347985 \\
\hline $\mathrm{R}$ & 0.017521 & -0.404467 & -0.421321 & 0.077944 & 1.000000 & 0.664379 & -0.914370 & -0.747890 & -0.770506 & -0.454561 \\
\hline RF & 0.071074 & -0.145300 & 0.251391 & 0.117218 & 0.664379 & 1.000000 & -0.770134 & -0.760251 & -0.770196 & -0.470740 \\
\hline EX RATE & 0.006842 & 0.345255 & -0.008980 & -0.070142 & -0.770506 & -0.770196 & 0.793384 & 0.775782 & 1.000000 & 0.502185 \\
\hline BOT & -0.157383 & -0.332970 & -0.118760 & -0.347985 & -0.454561 & -0.470740 & 0.563170 & 0.781213 & 0.502185 & 1.000000 \\
\hline
\end{tabular}

Figure 2. Macro external and internal variables correlation matrix

\subsection{Empirical Research Findings and Discussion}

In the below section, data used are from 2015-2020 with weekly data for stock price of Asian commercial bank (ACB), live data on VN stock exchange. Different scenarios are created by comparing 2 scenarios: macro internal factors impacts and macro external variables effects.

Market risk (beta) under the below model (Figure 3):

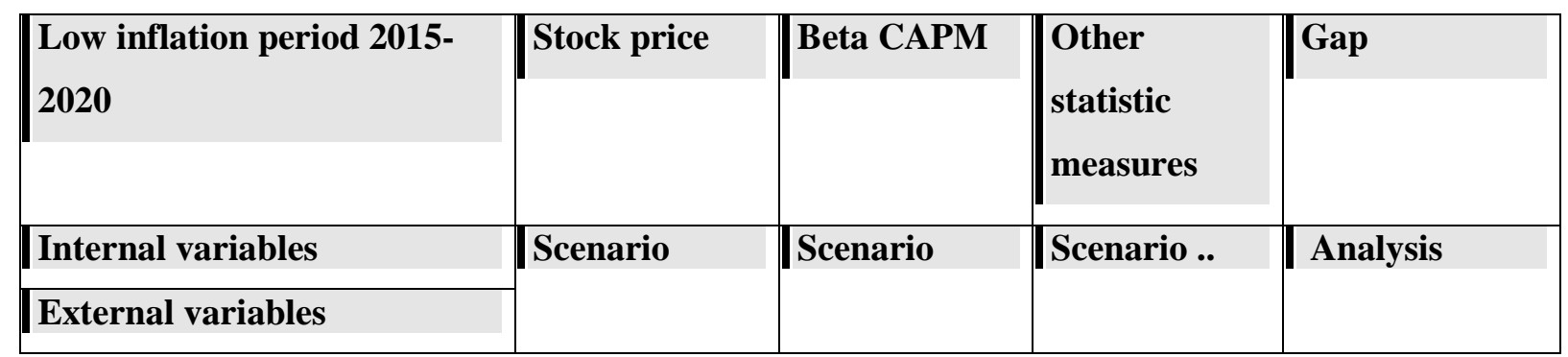

Figure 3. Calculating market risk under impacts from macro factors in 2 scenarios

Using OLS regression from Eviews, we find out: Balance of trade and SP500 have negative correlation with market risk of ACB while exchange rate has slightly positive correlation with Beta CAPM of ACB (Figure 4). 
ENTREPRENEURSHIP AND SUSTAINABILITY ISSUES

ISSN 2345-0282 (online) http://jssidoi.org/jesi/

2021 Volume 8 Number 3 (March)

http://doi.org/10.9770/jesi.2021.8.3(18)

Dependent Variable: BETACAPM

Method: Least Squares

Date: 01/01/21 Time: $14: 40$

Sample: 111

Included observations: 11

\begin{tabular}{lrlll}
\hline \hline Variable & Coefficient & Std. Error & t-Statistic & Prob. \\
\hline \hline BOT & -0.000627 & 0.001901 & -0.329774 & 0.7512 \\
EX_RATE & 0.000235 & 0.001135 & 0.206995 & 0.8419 \\
SP500 & $-4.43 \mathrm{E}-05$ & 0.001676 & -0.026413 & 0.9797 \\
C & -4.296450 & 22.99004 & -0.186883 & 0.8571 \\
\hline \hline R-squared & 0.034728 & Mean dependent var & 0.982799 \\
Adjusted R-squared & -0.378961 & S.D. dependent var & 0.825392 \\
S.E. of regression & 0.969251 & Akaike info criterion & 3.050701 \\
Sum squared resid & 6.576128 & Schwarz criterion & 3.195390 \\
Log likelihood & -12.77885 & F-statistic & 0.083946 \\
Durbin-Watson stat & 2.625422 & Prob(F-statistic) & 0.966640 \\
\hline \hline
\end{tabular}

Figure 4. External impacts on Beta CAPM

Looking at the below figure we see internal effects on Beta CAPM of ACB:G and CPI and risk free rate have higher impacts on ACB Beta CAPM, then lending rate rate. If risk free rate increases, market risk will increase (Figure 5).

\begin{tabular}{|c|c|c|c|c|}
\hline \multicolumn{5}{|c|}{$\begin{array}{l}\text { Date: } 01 / 01 / 21 \text { Time: } 14: 46 \\
\text { Sample: } 111 \\
\text { Included observations: } 11\end{array}$} \\
\hline Variable & Coefficient & Std. Error & t-Statistic & Prob. \\
\hline $\mathrm{CPI}$ & 10.30767 & 41.38333 & 0.249078 & 0.8156 \\
\hline G & -5.656530 & 48.56264 & -0.116479 & 0.9129 \\
\hline $\mathrm{IM}$ & 0.006252 & 0.011538 & 0.541862 & 0.6167 \\
\hline $\mathrm{R}$ & -0.847973 & 129.9411 & -0.006526 & 0.9951 \\
\hline RF & 9.063353 & 65.33558 & 0.138720 & 0.8964 \\
\hline VNINDEX & 0.000465 & 0.007505 & 0.061982 & 0.9536 \\
\hline $\mathrm{C}$ & -0.680716 & 17.49729 & -0.038904 & 0.9708 \\
\hline R-squared & 0.1936 & \multicolumn{2}{|c|}{ Mean dependent var } & 0.982799 \\
\hline Adjusted R-squared & -1.015754 & \multicolumn{2}{|c|}{ S.D. dependent var } & 0.825392 \\
\hline S.E. of regression & 1.171869 & \multicolumn{2}{|c|}{ Akaike info criterion } & 3.416203 \\
\hline Sum squared resid & 5.493106 & \multicolumn{2}{|c|}{ Schwarz criterion } & 3.669409 \\
\hline Log likelihood & -11.78912 & \multicolumn{2}{|l|}{ F-statistic } & 0.160154 \\
\hline Durbin-Watson stat & 3.057151 & \multicolumn{2}{|c|}{ Prob(F-statistic) } & 0.975154 \\
\hline
\end{tabular}

Figure 5. Internal impacts on Beta CAPM (ACB) 
ENTREPRENEURSHIP AND SUSTAINABILITY ISSUES

ISSN 2345-0282 (online) http://jssidoi.org/jesi/

2021 Volume 8 Number 3 (March)

http://doi.org/10.9770/jesi.2021.8.3(18)

Finally, Looking at the below figure we see internal effects on Beta CAPM of ACB:

We recognize that Trade balance, CPI, Industrial manufacturing have positive correlation or impacts on Beta CAPM, whereas other factors such as Risk free rate, GDP growth, Exchange rate and SP500 and lending rate have negative correlation with market risk (Beta of ACB). When GDP growth increases, beta CAPM of ACB will decreases, it is in favor of our $1^{\text {st }}$ hypothesis above. And if CPI increase the market risk will go up, it is in favor of our $1^{\text {st }}$ hypothesis. If exchange rate decreases (VND appreciation), it will makes market risk increase. It is NOT in favor of our $2^{\text {nd }}$ hypothesis (Figure 6).

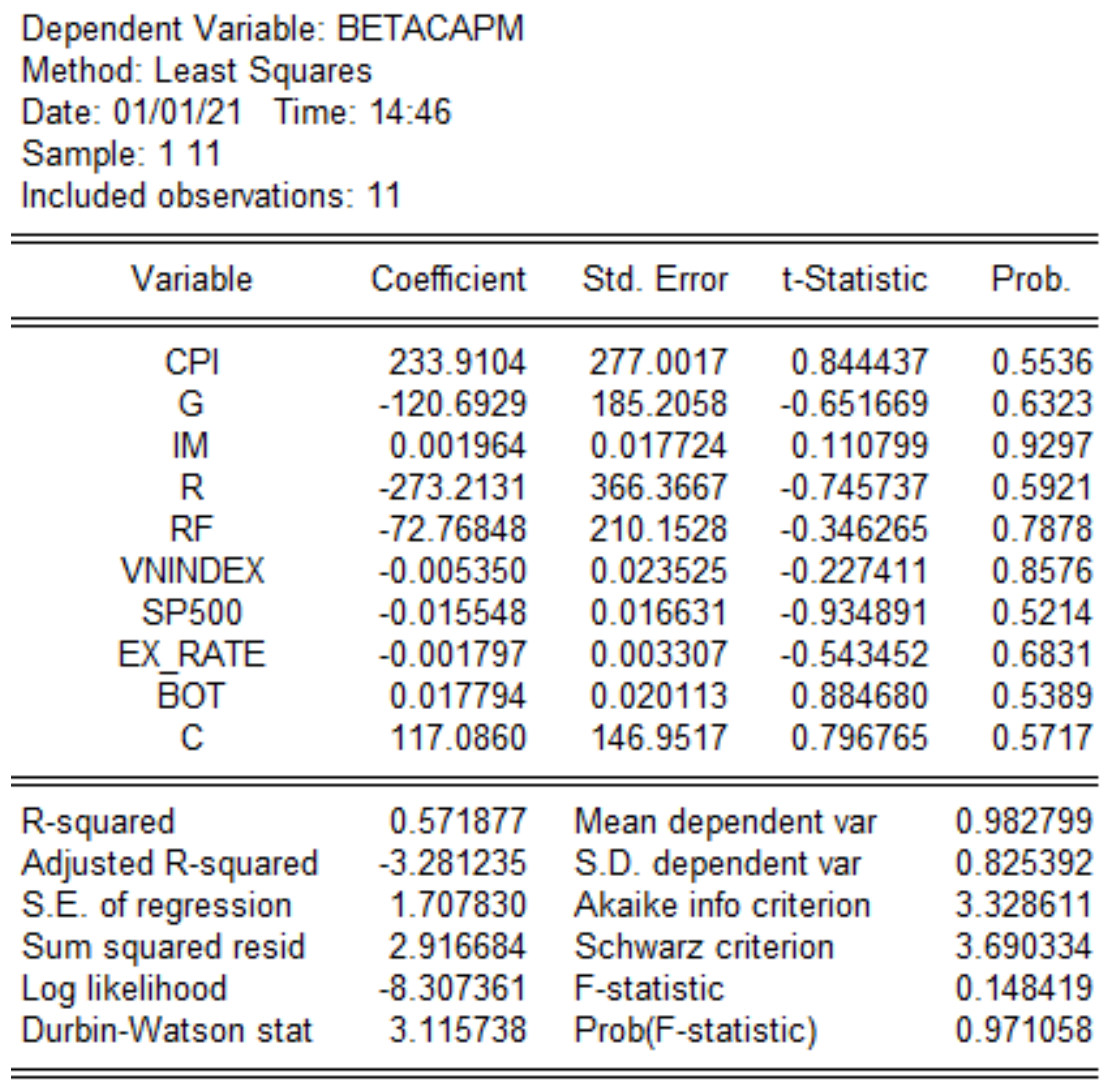

\section{Discussion for further researches}

Other macro factors such as (FDI, public debt, etc.) could be added in order to recommend suitable policies and plans to control market risk better.

In order to enhance risk management culture at $\mathrm{ACB}$, a big listed joint stock commercial bank in Vietnam, we have to consider some following action plans:

\section{Forms and activities of monitoring risk}

Risk monitoring is the continuous monitoring and control of activities to ensure achieving goals. It is a process of implementing controls, assessing activities continuously, independent evaluating and reporting results and defects that need to be resolve and overcome.

Monitoring risk in business life can be done periodically or randomly and it will help firms to recognize new risks happening in ongoing business activities. Monitoring risk can be performed at the division, branch levels or from 
head quarters and under the form of risk report in which we might analyze risk root causes and suggest preventive or corrective actions, functioned as risk responses and may require changes.

In risk report, we could identify new risks and risk trend, or cost trend and price trend, etc.

Normally, there are two methods of risk monitoring as following:

First, it is continuous monitoring (assessment of KPI business management: turnover, cash, financial indicators, operational statistics, comparison of production, inventory, quality, sales, etc.)

Second, monitoring is done through separate evaluation. The below figure 7 will explain more.

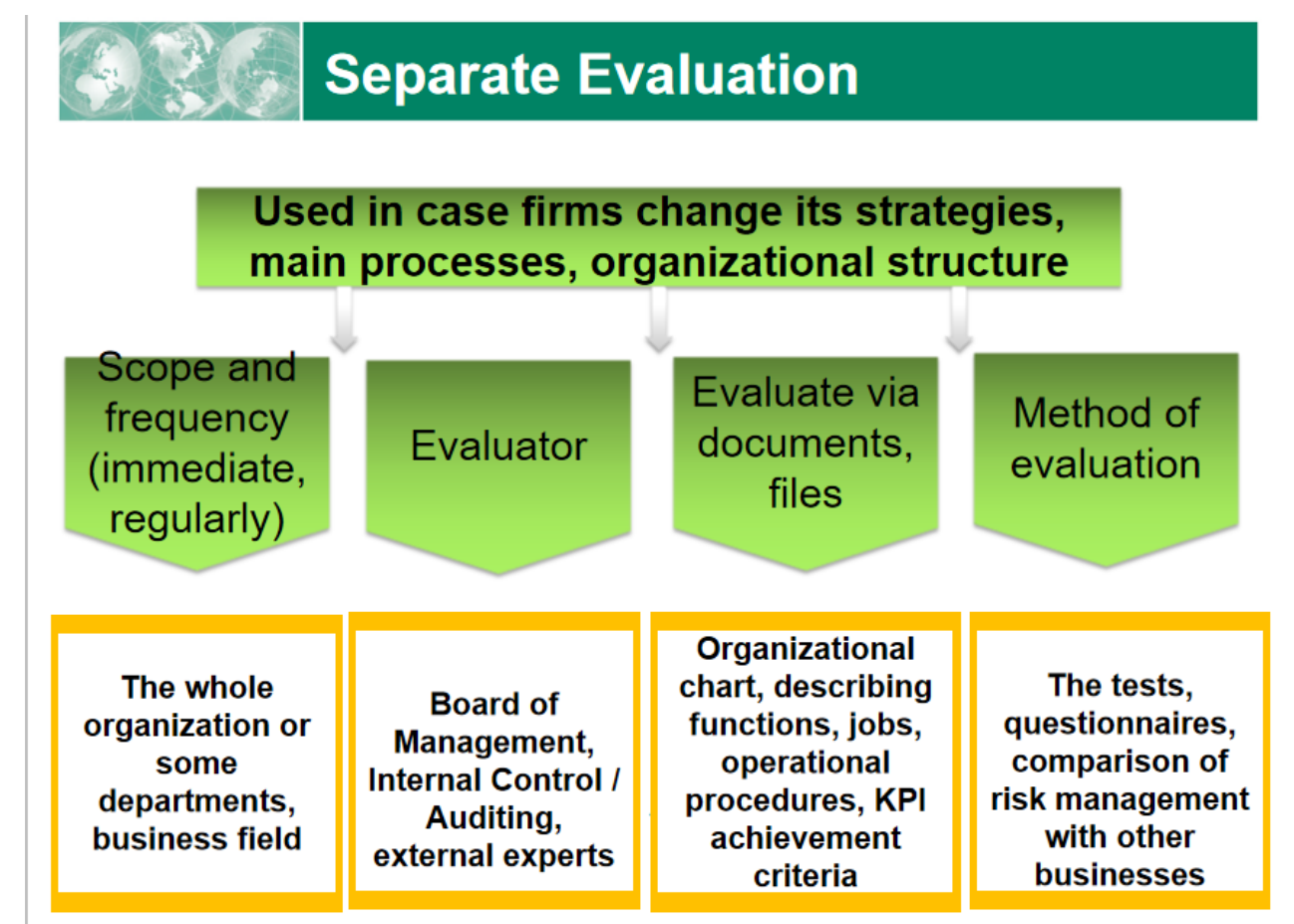

Figure 7. Explanation of Separate Evaluation

\section{Conclusion and Policy suggestion}

As shown from the above regression model and equation, Goverment and Ministry of Finance need to increase GDP growth and reduce CPI for lower market risk. This research paper provides evidence that the market risk are affected much more by CPI, GDP growth, risk free rate and lending rate. It means that the role of bank system in trying to control credit growth and rates reasonably.

Our model also shows that other macro factors such as VNIndex and exchange rate just have slight impact on Beta CAPM. And macro internal factors have much more effects on market risk of Asia commercial bank (ACB).

\section{Policy implications:}

Specifically, for banks and companies listed on Vietnam's stock market, in the context that bank loans tend to reduce since 2018 (see exhibit 1): 
ENTREPRENEURSHIP AND SUSTAINABILITY ISSUES

ISSN 2345-0282 (online) http://jssidoi.org/jesi/

2021 Volume 8 Number 3 (March)

http://doi.org/10.9770/jesi.2021.8.3(18)

- Building a Beta CAPM /market risk measurement model as described above through the stages to monitor risks of key financial services industries including listed banks on Vietnam stock market

- Building a model to analyze the impact of macro variables on Beta CAPM for the financial services sector as described above.

Moreover, the government and relevant bodies such as Ministry of Finance and State Bank of Vietnam need to consider proper policies (including a combination of fiscal, monetary, exchange rate and price control policies) aiming to reduce the risk volatility and hence, help the bank system as well as the whole economy become more stable in next development stage. The Ministry of Finance continue to increase the effectiveness of fiscal policies and tax policies which are needed to combine with other macro policies at the same time. The State Bank of Viet Nam continues to increase the effectiveness of capital providing channels for medicine companies as we could note that in this study, debt leverage has certain impacts on reducing risk level.

Risk management culture implications:

- Suggestions for some risk management activities at enterprise and bank level are as follows:

Make a risk recognition report; Promulgating the Code of Professional Ethics; Regulations that employees are not allowed to disclose internal information; Strengthen legal communication to raise awareness and compliance; Issue the Internal Control Procedures

- With the application of macro-variable impact analysis on Beta CAPM, businesses and banks need to develop two risk causation analyzes according to the $5 \mathrm{M}$ model as follows (from which proposing solutions to minimize risks): Man-Machine-Method-Material-Money.

Last but not least, we can use DMAIC model combined with Separate evaluation for risk monitoring as shown in the below model (Figure 8):

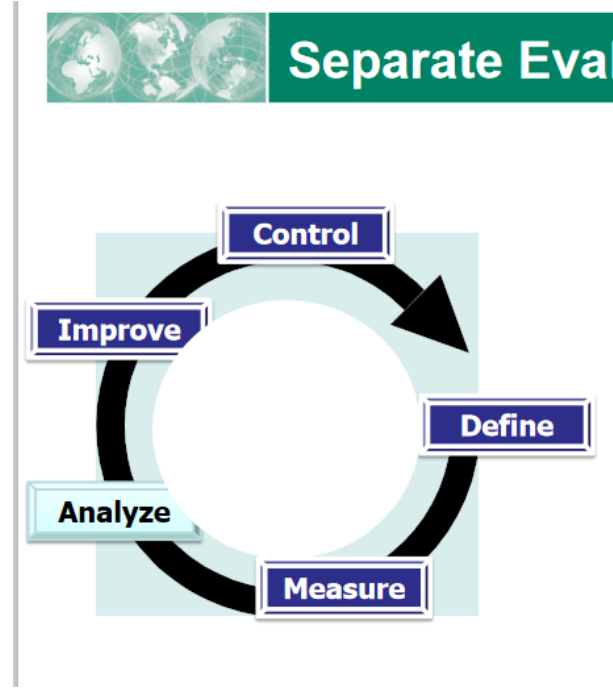

Set up meeting minutes to make effective decisions

Report to the CEO serious violations of procedures and policies

Report to the management board the defects of risk management and the control of the unit in charge

Figure 8. The process of risk monitoring with DMAIC model

Here we refer to the using of Six Sigma DMAIC model to: firstly, define scope of risk monitoring and risk scope; secondly, measure risks and safety of working place and business environment; thirdly, analyze root causes of risk; fourthly, improving and resolving defects after knowing root causes and finally, control or re-evaluation of changes made, whether It is effective or bad. 


\section{ENTREPRENEURSHIP AND SUSTAINABILITY ISSUES}

ISSN 2345-0282 (online) http://jssidoi.org/jesi/

2021 Volume 8 Number 3 (March)

http://doi.org/10.9770/jesi.2021.8.3(18)

The role of risk monitoring is presented through risk assessment results sharing, coordination and communication and from that, we could propose proper risk responses and build trust.

\section{Limitation of the research:}

Finally, this study opens some new directions for further researches in risk control policies in medicine system as well as in the whole economy. We also can add other factors such as public debt into our model for expanding research. Even we can expand our research model for other Vietnam industries as well as in other emerging markets and all over the world.

\section{References}

Adhikari. N. (2015). Determinants of Systemic Risk for Companies Listed on Nepal Stock Exchange. Global Journal of Management and Business Research: Finance, 15(5), 75-83.

Ahmad, N., \& Ramzan, M. (2016). Stock Market Volatility and Macroeconomic Factor Volatility. International Journal of Research in Business Studies and Management, 3(7), 37-44.

Andersen, T.G., Bollerslev, T., Diebold, F.X., \& Wu, J. (2005). A Framework for Exploring the Macroeconomic Determinants of Systematic Risk. Financial Economics. Macroeconomics, and Econometrics, 95(2), 398-404.

Anwar, S. (2020). Weighting on Systemic Important Banking (SIB) in Indonesia: The Official Versus PCA Approaches. Journal of Central Banking Theory and Practice, 9(2), 155-182.

Arnes, S.K. (2014). Impact of Macroeconomic Indicators on Stock Market Performance: The Case of The Istanbul Stock Exchange. Master Thesis, Copenhagen Business School. Retrieved from: https://research-api.cbs.dk/ws/portalfiles/portal/58450158/sibel_arnes.pdf

Bayar, Y. (2020). Macroeconomic, Institutional and Bank-Specific Determinants of Non-Performing Loans in Emerging Market Economies: A Dynamic Panel Regression Analysis. Journal of Central Banking Theory and Practice, 9(2), 95-110.

Be, N.T, \& Hung, B.Q. (2019). Sytematic risk in banking in stages of crisis, Finance Journal. Retrieved from: http://tapchitaichinh.vn/nganhang/rui-ro-he-thong-trong-hoat-dong-kinh-doanh-ngan-hang-o-cac-giai-doan-khung-hoang-302120.html

Bohachova, O. (2008). The Impact of Macroeconomic Factors on Risks in the Banking Sector: A Cross-Country Empirical Assessment. IAW Discussion Papers 44, Institut für Angewandte Wirtschaftsforschung (IAW).

Bowman, R.G. (1979). The Theoretical Relationship between Systematic Risk and Financial (Accounting) Variables. The Journal of Finance, 34(3), 617-630.

Butt, B.Z., \& Rehman, K.U. (2010). Do economic factors influence stock returns? A firm and industry level analysis. African Journal of Business Management, 4(5), 583-593.

Celebi, K., \& Honig, M. (2019). The Impact of Macroeconomic Factors on the German Stock Market: Evidence for the Crisis, Pre- and Post-Crisis Periods. International Journal of Financial Studies, 7(18). https://doi.org/10.3390/ijfs7020018

Claudia, M.P., Sandra, E., \& Esteban, P. (2010). Macroeconomic factors and micro-level bank risk. Discussion Paper Series 1: Economic Studies No 20/2010.

Curran, M., \& Velic, A. (2018). The CAPM, National Stock Market Betas, and Macroeconomic Covariates: A Global Analysis'. Trinity Economics Papers 0618, Trinity College Dublin, Department of Economics.

Donzwa, W., Gupta, R., \& Woha, M.E. (2020). Volatility Spillovers between Interest Rates and Equity Markets of Developed Economies. Journal of Central Banking Theory and Practice, 9(2), 39-50.

Emilios, A. 2015. Bank Leverage Ratios and Financial Stability: A Micro- and Macroprudential Perspective, Working Paper No.849, Levy Economics Institute. 


\section{ENTREPRENEURSHIP AND SUSTAINABILITY ISSUES}

ISSN 2345-0282 (online) http://jssidoi.org/jesi/

2021 Volume 8 Number 3 (March)

http://doi.org/10.9770/jesi.2021.8.3(18)

Ercegovac, R., Pecaric, M., \& Klincac, I. (2020). Bank Risk Profiles and Business Model Characteristics. Journal of Central Banking Theory and Practice, 9(3), 107-121.

Eugene, F.F, \& French, K.R. (2004). The Capital Asset Pricing Model: Theory and Evidence. Journal of Economic Perspectives, 18(3), 2546. https://doi.org/10.1257/0895330042162430

Gay, R.D. (2016). Effect Of Macroeconomic Variables On Stock Market Returns For Four Emerging Economies: Brazil, Russia, India, And China. International Business \& Economics Research Journal, 15(3)

Gocer, I., \& Ongan, S. (2020). The Relationship between Inflation and Interest Rates in the UK: The Nonlinear ARDL Approach. Journal of Central Banking Theory and Practice, 9(3), 77-86.

Gizycki, M. (2001). The Effect of Macroeconomic Conditions on Bank Risks and Profitability. Research Discussion Paper 2001-06, System Stability Department Reserve Bank of Australia. Retrieved from: https://www.rba.gov.au/publications/rdp/2001/pdf/rdp200106.pdf

Hojat, S. (2015). The Impact of Monetary Policy on the Stock Market, Doctoral dissertation, Walden University. Retrieved from: https://scholarworks. waldenu.edu/cgi/viewcontent.cgi?article $=2602 \&$ context=dissertations

Hanif, M.N., Iqbal, J., Ali, S.H., \& Salam, M.A. (2020). Denoised Inflation: A New Measure of Core Inflation. Journal of Central Banking Theory and Practice, 9(2), 131-154.

Harjito, D. A., Mohamed, Z., Mohamed, N., \& Zainudin, Z. (2020). Bringing various dimensions of credit of ASEAN countries for scrutiny: implications on sustainable economic growth. Journal of Security and Sustainability Issues, 10(Oct), 338-348. https://doi.org/10.9770/jssi.2020.10.Oct(27)

Huey-Yeh, L., Nuraeni, H.F., \& Meihua, K. (2016). The Impact of Macroeconomic Factors on Credit Risk in Conventional Banks and Islamic Banks: Evidence from Indonesia. International Journal of Financial Research, 7(4).

Huong, N.T. (2017). Average rate of return theory of K. Marx and CAPM model. Finane Journal http://tapchitaichinh.vn/nghien-cuutraodoi/ly-thuyet-ty-suat-loi-nhuan-binh-quan-cua-k-marx-va-mo-hinh-dinh-gia-tai-san-von-132532.html

Huy, D.T.N., Dat, P. M., \& Anh, P. T. (2020). Building and econometric model of selected factors' impact on stock price: a case study. Journal of Security and Sustainability Issues, 9(M), 77-93. https://doi.org/10.9770/jssi.2020.9.M(7)

Huy, D.T.N., Nhan V.K., Bich N.T.N., Hong N.T.P., Chung N.T., \& Huy P.Q. (2021). Impacts of Internal and External Macroeconomic Factors on Firm Stock Price in an Expansion Econometric model-A Case in Vietnam Real Estate Industry. Data Science for Financial Econometrics-Studies in Computational Intelligence, 898, Springer. http://doi-org-443.webvpn.fjmu.edu.cn/10.1007/978-3-030-48853$\underline{6 \_14}$

Kola, F., Gzipali, A., \& Sula, E. (2020). Commercial Bank Performance and Credit Risk in Albania, Journal of Central Banking Theory and Practice, 9 (2), 161-177.

Kozaric, K., \& Dzelihodzic, E.Z. (2020). Effects of Macroeconomic Environment on Non-Performing Loans and Financial Stability: Case of Bosnia and Herzegovina. Journal of Central Banking Theory and Practice, 9(2), 5-17.

Kruscovic, B. (2020). Exchange Rate Targeting Versus Inflation Targeting: Empirical Analysis of the Impact on Employment and Economic Growth, Journal of Central Banking Theory and Practice, 9(2), 67-85.

Kuek, T.H., Puah, C.H., \& Arip, M.A. (2020). Financial Vulnerability and Economic Dynamics in Malaysia, Journal of Central Banking Theory and Practice, 9 (s1), 55-73.

Kumaresan, R. (2019). The Effects of Macroeconomics Factors towards the Starbucks Corporation, MPRA Paper No. 97243. Retrieved from: https://mpra.ub.uni-muenchen.de/97243/1/MPRA paper 97243.pdf

Kuncoro, H. (2020). Interest Rate Policy and Exchange Rates Volatility Lessons from Indonesia, Journal of Central Banking Theory and Practice, 9(2), 19-42. 


\section{ENTREPRENEURSHIP AND SUSTAINABILITY ISSUES}

ISSN 2345-0282 (online) http://jssidoi.org/jesi/

2021 Volume 8 Number 3 (March)

http://doi.org/10.9770/jesi.2021.8.3(18)

Lintner, J. (1965). The Valuation of Risk Assets and The Selection of Risky Investments in Stock Portfolios and Capital Budgets. The Review of Economics and Statistics, 47, 13-37.

Masood, O., Javaria, K., \& Petrenko, Y. (2020). Terrorism activities influence on financial stock markets: an empirical evidence from United Kingdom, India, France. Pakistan, Spain and America. Insights into Regional Development, 2(1), 443-455. https://doi.org/10.9770/IRD.2020.2.1(4)

Mossin, J. (1966). Equilibrium in A Capital Asset Market. Econometrica, 34(4), 768-783.

Nain, Z., \& Kamaiah, B. (2020). Uncertainty and Effectiveness of Monetary Policy: A Bayesian Markov Switching-VAR Analysis. Journal of Central Banking Theory and Practice, 9 (s1), 237-265.

Nawaz. R., Ahmed, W., Imran, Sabir, S., \& Arshad, M. (2017). Financial Variables and Systematic Risk. Chinese Business Review, 16(1), 36-46. https://doi.org/10.17265/1537-1506/2017.01.004

Okpamen, H., \& Ogbeide, S.O. (2020). Board director reputation capital and financial performance of listed firms in Nigeria. Insights into Regional Development, 2(4), 765-773. http://doi.org/10.9770/IRD.2020.2.4(3)

Patro, D.K., Wald, J., \& Wu, Y. (2002). The Impact of Macroeconomic and Financial Variables on Market Risk: Evidence from International Equity Returns, European Financial Management, 8(4), 421 - 447. http://doi.org/10.1111/1468-036X.00198

Pena, G. (2020). Monetary Policy after the Great Moderation, Journal of Central Banking Theory and Practice, 9(3), 5-26.

Puspitaningtyas, Z. (2017). Estimating systematic risk for the best investment decisions on manufacturing company in Indonesia. Investment Management and Financial Innovations, 14(1), 46-54. https://doi.org/10.21511/imfi.14(1).2017.05

Quang, T.M., Minh, H.C., Linh, L.T.B., Thiem, N.H., \& Tuyet, L.T. (2019). Factors affect stock return from perspective of 5 factor FamaFrench model. Finance Journal. Retrieved from: http://tapchitaichinh.vn/kinh-te-vi-mo/yeu-to-tac-dong-den-ty-suat-sinh-loi-cua-co-phieuniem-yet-nhin-tu-mo-hinh-5-nhan-to-fama-french-315676.html

Rakotonirainy, M., Rajafindravonona, J., \& Rasolomanana, C. (2020). Macro Stress Testing Credit Risk: Case of Madagascar Banking Sector. Journal of Central Banking Theory and Practice, 9(2), 199-218.

Rakshit, B., \& Bardhan, S. (2020). Does Bank Competition Enhance or Hinder Financial Stability? Evidence from Indian Banking. Journal of Central Banking Theory and Practice, 9(s1), 75-102.

Rumondor, B.Y., \& Bary, P. (2020). Capital Flows and Bank Risk-Taking Behavior: Evidence From Indonesia. Journal of Central Banking Theory and Practice, 9(s1), 33-53.

Sadeghzadeh, K. (2018). The effects of microeconomic factors on the stock market: A panel for the stock exchange in Istanbul ARDL analysis. Theoretical and Applied Economics Volume XXV, 3(616), 113-134.

Saeed, S., \& Akhter, N. (2016). Impact of Macroeconomic Factors on Banking Index in Pakistan. Interdisciplinary Journal of Contemporary Research in Business, 4(6)

Singh, T., Mehta, S., \& Versha, M.S. (2010). Macroeconomic factors and stock returns: Evidence from Taiwan. Journal of Economics and International Finance, 2(4), 217-227.

Sharpe, W.F. (1964). Capital Asset Prices: A Theory of Market Equilibrium Under Conditions of Risk. The Journal of Finance, 19(3), 425442 .

Siregar, E. I., \& D. (2019). The Impact of Political Risk and Macro Economics on Stock Return at Indonesia Stock Exchange (An Approach of Arbritage Pricing Theory (APT)) KnE Social Sciences, 3(26), 744-772. https://doi.org/10.18502/kss.v3i26.54

Sun, L. (2020). On the People's Bank of China's Financial Strength and Policy Outcomes. Journal of Central Banking Theory and Practice, 9(3), 135-161.

Tahir, M., Ibrahim, H., Zulkafli, A.H., \& Mushtaq, M. (2020). Influence of Exchange Rate Fluctuations and Credit Supply on Dividend Repatriation Policy of U.S. Multinational Corporations. Journal of Central Banking Theory and Practice, 9(s1), $267-290$. 
Tahmidi, A. Westlund, S.A., \& Sheludchenko, D. (2011). The Effect of Macroeconomic Variables on Market Risk Premium, Working paper, Mälardalen University. Retrieved from: https://www.diva-portal.org/smash/get/diva2:429080/FULLTEXT01.pdf

Tanaka, A. (2020). Monetary Base Controllability after an Exit from Quantitative Easing, Journal of Central Banking Theory and Practice, 9(3), 123-134.

Taruna, A.A., Harun, C.A., \& Nattan, R.R. (2020). Macroprudential Liquidity Stress Test: An Application to Indonesian Banks. Journal of Central Banking Theory and Practice, 9(s1), 165-187.

Treynor, J.L. (1962). Toward a Theory of Market Value of Risky Asset. Draft. Final version published in 1999, Asset Pricing and Portfolio Performance, Robert A. Korajyczyk (editor) London: Risk books, 15-22.

Vucinic, M. (2020). Fintech and Financial Stability Potential Influence of FinTech on Financial Stability, Risks and Benefits. Journal of Central Banking Theory and Practice, 9(2), 43-66.

Tkacova, A., Kubak, M., Androniceanu, A., Tvaronavičienè, M., Eva Huculova, E. (2018). Financial literacy of students in chosen universities - research platform for regulatory processes of educational system in Slovakia, E + M. Economics and Management, 21 (1), 175-190. https://doi.org/10.15240/tul/001/2018-1-012

Tvaronavičienė, M., Masood, O., Javaria, K. (2018). Preconditions of the Eurozone economic security: how to overcome liquidity risk and cost inefficiency in leading banks of UK and Germany, Polish journal of management studies, 18(1), 418-427.

https://doi.org/10.17512/pjms.2018.18.1.31

\section{Exhibit}

Exhibit 1. Loan/Credit growth rate in the past years (2012-2018) in Vietnam

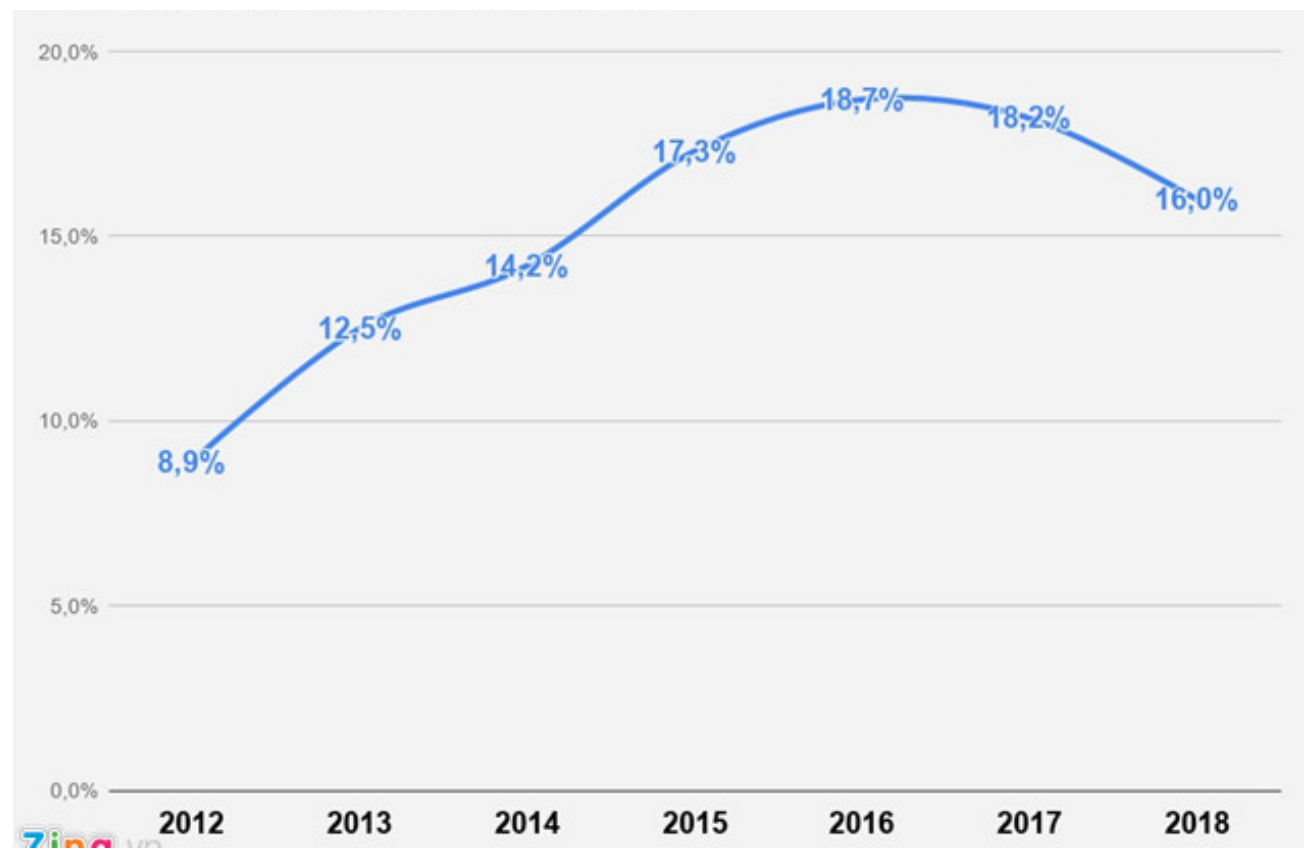




\section{Le Dinh HAC}

ORCID: 0000-0003-2961-9088

Dinh Tran Ngoc HUY

ORCID: 0000-0002-2358-0699

Nguyen Ngoc THACH

ORCID: 0000-0001-8822-2633

Bui Minh CHUYEN

ORCID: 0000-0003-1584-5017

Pham Thi Hong NHUNG

ORCID: 0000-0002-0441-402X

Tran Duc THANG

ORCID: 0000-0002-5148-7723

Tran Tuan ANH

ORCID: 0000-0002-0503-888X

Copyright (C) 2021 by author(s) and VsI Entrepreneurship and Sustainability Center

This work is licensed under the Creative Commons Attribution International License (CC BY).

http://creativecommons.org/licenses/by/4.0/

(c) (i) Open Access 